\title{
Phylogenetic Relationships of the Genus Hemerocallis in Korea using rps16-trnk Sequences in Chloroplast DNA
}

\author{
Man Kyu Huh" ${ }^{1}$, Oh Sung Kwon', and Byeong Ryong Lee ${ }^{2}$ \\ ${ }^{1}$ Department of Molecular Biology, Dong-eui University, Busan 614714, Korea \\ ${ }^{2}$ Department of Biology Education, Seowon University, Chungbuk 361-742, Korea
}

Received January 24, 2013 /Revised May 20, 2013 /Accepted June 28, 2013

\begin{abstract}
The genus Hemerocallis (family Xanthorthoeaceae) is a herbaceous species, some of which are very important in herbal medicines. We evaluated the rps16-trnK region of the chloroplast DNA of a representative sample of eight taxa in Korea to estimate phylogenetic relationships within the taxa of this genus. Due to differences in the number of inserted nucleotides, the aligned data for Hemerocallis ranged from 729 (H. aurantiaca) to 742 nucleotides ( $H$. fulva var. kwanso), with a mean of 736 . Although several small indels and 20 inserts were present, sequence variation within the Hemerocallis genus was mostly due to nucleotide substitutions. All rps16-trnK trees generated in Korea exhibited a well-solved topology, with high bootstrap support, irrespective of the methods (parsimony) and the setting used. The node of $H$. minor and $H$. littorea was strongly supported, with a high bootstrap value in three trees, and these two taxa were sistered with $H$. thunbergii. The number of chromosomes was not congruent with that found in a previous study with RAPD, but the number was in agreement with the results of this study.
\end{abstract}

Key words : Hemerocallis, rps16-trnK, phylogenetic relationships, sequence variation

\section{Introduction}

Daylily is the general nonscientific name of a species, hybrid or cultivar of the genus Hemerocallis (Family Hemerocallidaceae or Xanthorthoeaceae, Order Asparagales). Hemerocallis is low-growing perennial species. Hemerocallis is native to Eurasia and mainly found in the Asia (mainly China, Korea and Japan) $[12,19]$. Hemerocallis is one of the very highly hybridized plant genera. Thus, the flowers of their plants have hybridized by gardening enthusiasts. Thus the flowers and plants are highly diverse in color and form. Hybridizers register hundreds of new cultivars yearly [12, 23].

Classification of species has been at the heart of all plant systematics. The classification process generally tries to arrange plants into a logical form and doing so to sort the species in some evolutionary manner. Hemerocallis is a taxonomically problematic group because of variations of morphological characters (even within a species) and difficulty in defining specific boundaries, as summarized by Zomlefer

\footnotetext{
*Corresponding author

Tel : +82-51-890-1529, Fax : +82-51-890-1521

E-mail : mkhuh@deu.ac.kr

This is an Open-Access article distributed under the terms of the Creative Commons Attribution Non-Commercial License (http://creativecommons.org/licenses/by-nc/3.0) which permits unrestricted non-commercial use, distribution, and reproduction in any medium, provided the original work is properly cited.
}

[23]. For example, Chung [2] has provided a detailed study of three populations of the species Hemerocallis hakuensis and has shown that there is a significant within species variation by alloymes. Noguchi et al. [13] reported that the separation of this species had occurred in conjunction with the geological vicariance or orogeny. These studies have been reported for many years $[3,6,7,11,18-20]$. This was a problem for many plant sytematicists who had few examples of species available and used this limited number to describe the species. Noguchi and Hong [12] have well studied the origin and evolution of the Japanese nocturnal Hemerocallis citrina var. vespertina by the nucleotide sequences of three noncoding chloroplast regions. Their work included a detailed analysis of certain exons and an understanding of the evolution of this species. It is necessary to perform extensive field work to fully understand the within species variation.

The rps16-trnK region in chloroplast DNA usually shows sequence conservation in the regions flanking both trnL exons, whereas the central part is highly variable [16]. Within the intergenic spacer, no secondary-structural elements have been found that could serve as splicing points, including that rps16-trnK are probably co-transcribed [1, 14]. A general feature of cpDNA spacer regions is the occurrence of indels that can be derived from either deletion or duplication of adjacent sequences or occur in non-repetitive regions of the spacer [5]. 
We analyzed intra- and interspecific phylogenic relationships within genus Hemerocallis in Korea and to compare with the results of previous studies of this genus.

\section{Materials and Methods}

\section{Sample materials}

Seven species and one variety were selected to represent main lineages within genus Hemerocallis, Hemerocallis dumortieri, Hemerocallis coreana, Hemerocallis dumortieri var. esculenta, Hemerocallis thunbergii, Hemerocallis minor, Hemerocallis aurantiaca, Hemerocallis fulva var. kwanso, and Hemerocallis littorea (Table 1).

$H$. dumortieri is a vigorous clump-forming species that grows about $0.3 \mathrm{~m}$ tall. Each flowering stem carries up to eight trumpet-shaped flowers that are about three inches long. This is one of the first species to come into flower, in May and June, each flower living less than a day.

$H$ coreana is a clumping species growing about $1.0 \mathrm{~m}$ tall and has yellow flowers. The species has a long flowering season, from May to July, and individual flowers live longer than in most Hemerocalis species. The species has a fibrous root system with occasional spindle-like edible swellings.

$H$. dumortieri var. esculenta is a vigorous clumping plant growing about $0.6 \mathrm{~m}$ tall. It is cultivated in the Orient for its edible flowers. The flowers, which are produced in June and July, are up to $10 \mathrm{~cm}$ long with 5-6 blooms carried on each flowering stem. This species does not have swollen roots.

H. thunbergii is a perennial growing to $0.5 \mathrm{~m}$ by $0.5 \mathrm{~m}$. It is in flower from July to August. The flowers are hermaphrodite (have both male and female organs).

H. minor grows about $0.3 \mathrm{~m}$ tall, flowering in May and June. The flowers are about $5 \mathrm{~cm}$ long with, up to 5 being carried on each flowering stem. They open in the evening and are relatively long-lived, with individual blooms lasting up to 3 days. This species has small bulbous swellings at the ends of its roots which have a mild radish-like favor.

$H$. aurantiaca grows about $1.0 \mathrm{~m}$ tall. It flowers from June to August. There are a number of named forms, most if not all of which are sterile triploids and will not produce seed. The pollen, however, is fertile and can be used to fertilize other plants. Cultivated for its flowers in China, Korea, and Japan, these are usually harvested as they start to wither and then dried. The roots have edible spindle-shaped swellings.

$H$ fulva var. kwanso is a variegated form with white stripes along the length of the leaves. The flowers are about $15 \mathrm{~cm}$ long.

$H$. littorea is a perennial growing to $0.9 \mathrm{~m}$ by $0.6 \mathrm{~m}$. It is hardy to zone 4 and is not frost tender. It is in flower from August to September, and the seeds ripen from September to October. The flowers are hermaphrodite (have both male and female organs).

Hosta capitata and Hosta lancifolia were used as outgroup species in this study.

\section{DNA extract}

The genomic DNA of the samples was extracted from fresh leaves using the Plant DNA Zol Kit (Life Technologies Inc., Grand Island, New York, U.S.A.) according to the manufacturer's protocol. Briefly, sample per species was ground to fine powder in liquid nitrogen and mixed buffer of Plant DNA Zol. The sample was shaken gently at room temperature for $10 \mathrm{~min}$. After adding 24:1 chloroform/isoamyl alcohol, the sample was centrifuged at $12,000 \mathrm{~g}$. The DNA precipitate was recovered with $70 \%$ ethanol, dried, and dissolved in TE buffer. Concentration of extracted DNA was measured by Bio-Rad (Bio-Rad Laboratories, Inc., Hercules,

Table 1. Numberic codes and population location of genus Hemerocallis

\begin{tabular}{lll}
\hline Codes & \multicolumn{1}{c}{ Scientific names } & \multicolumn{1}{c}{ Localities } \\
\hline HDU & Hemerocallis dumortieri Morren & Cheongha-myeon, Buk-gu, Pohang-si, Gyeongsangbukdo \\
HCO & Hemerocallis coreana Nakai & $\begin{array}{c}\text { Cheongha-myeon, Buk-gu, Pohang-si, Gyeongsangbukdo } \\
\text { Sohol-eup, Pocheon-si, Gyeonggido }\end{array}$ \\
HDE & Hemerocallis dumortieri Morren var. esculenta (Koidz.) & \\
HTH & Kitammura & Ongyong-myeon, Kwangyang-si, Jeollanamdo \\
HMI & Hemerocallis thunbergii Baker & Seorak-myeon, Gapyeng-gun, Gyeonggido \\
HAU & Hemerocallis aurantiaca Baker & Sucheong-dong, Osan-si, Gyeonggido \\
HFU & Hemerocallis fulva var. kwanso Regel & Sohol-eup, Pocheon-si, Gyeonggido \\
HLI & Hemerocallis littorea M. Hotta & Heuksan-myeon, Sinan-gun, Hongdo, Jeollanamdo \\
HCA & Hosta capitata (Koidz.) Nakai & Gonmyeong-myeon, Sacheon-si, Gyeongsangnam-do \\
HLA & Hosta lancifolia Engler & Gonmyeong-myeon, Sacheon-si, Gyeongsangnam-do \\
\hline
\end{tabular}


CA, USA).

\section{rps16-trrk analysis}

The rps16-trnK region of the chloroplast genome were amplified using primer sets $[1,14]$ by polymerase chain reaction (PCR) using standard techniques at a $2.5 \mathrm{mmol} / \mathrm{l} \mathrm{MgCl}_{2}$ concentration. The following pairs were employed for the makers. rpsi6-F : 5'-AAAGGKTGCTCARCCTACARGAA-3', trnK-R : 5'-TACTCTACCRTTGAG TTAGCAAC-3 ${ }^{\star}$.

PCR materials (50 $\mu \mathrm{l}$ volume) included $50 \mathrm{ng}$ of genomic DNA, $100 \mathrm{uM}$ of each dNTP, $0.2 \mathrm{uM}$ of each primer, $1 \mathrm{x}$ enzyme buffer, and 2 unit of Taq polymerase. The amplification profile was 28 cycles of $94^{\circ} \mathrm{C}$ for $30 \mathrm{sec}, 42^{\circ} \mathrm{C}$ for 60 sec, $72^{\circ} \mathrm{C}$ for $60 \mathrm{sec}$, preceded by an initial denaturation at $94{ }^{\circ} \mathrm{C}$ for $90 \mathrm{sec}$ and followed by a final extension at $72^{\circ} \mathrm{C}$ for $5 \mathrm{~min}$.

PCR products were separated on 2.0\% agarose gels and purified using the QIAquick Gel Extraction Kit (QIAGEN). The amplified fragments were cloned into a bluescript vector and sequenced using ABI Prism 377 Sequencer (Applied Biosystem, USA). At least seven individuals' clones of each species were analyzed.

\section{Alignment and phylogenetic analysis}

The chromatogram output for each sample was edited using the software Sequence Navigator 1.0.1 (Applied Biosystems Inc.), and the sequences were manually aligned. A pairwise alignment was calculated using the ClustalX program.

Estimates of evolutionary divergence between sequences were conducted using the maximum composite likelihood model [21]. Models with the lowest BIC scores (Bayesian Information Criterion) are considered to describe the substitution pattern the best [8]. For each model, AICc value (Akaike Information Criterion, corrected), Maximum
Likelihood value $(\ln L)$, and the number of parameters (including branch lengths) are also presented. Non-uniformity of evolutionary rates among sites may be modeled by using a discrete Gamma distribution $(+G)$ with 5 rate categories and by assuming that a certain fraction of sites are evolutionarily invariable $(+I)$. Whenever applicable, estimates of gamma shape parameter and/or the estimated fraction of invariant sites are shown. Assumed or estimated values of transition/transversion bias $(R)$ are shown for each model, as well.

Phylogenetic relationship were estimated by MEGA5 [22] and PAUP version $4.0 \mathrm{~b} 10$ [17] treating all alignment gaps as missing. A maximum parsimony tree (MP) was inferred using heuristic search, branch-swapping options and tree bisection-reconnection. Confidence values for individual branches were determined by a bootstrap analysis with 100 repeated sampling of the data. Maximum likelihood (ML) was implanted in GARLI ver. 0.951 [24] starting from random trees and using 10,000,000 generations per search. In addition, a phylogenetic tree was constructed by the neighbor-joining (NJ) method [15] using the NEIGHBOR program in PHYLIP version 3.57 [4].

\section{Results}

The complete sequences of chloroplast rps16-trnK regions were PCR amplified and sequenced for the eight Korean distributed species of genus Hemerocallis and two outgroup species. The aligned data sets for Hemerocallis range from 729 (H. aurantiaca) to 742 nucleotides (bp) (H fulva var. kwanso) with a mean of 736 as a results of differences in insert nucleotides (Table 1). The final aligned data matrix contained 767 positions, of which 12 were excluded from subsequent analyses because of ambiguities. Thus we used the 751 positions.

Table 2. The base frequencies across taxa of genus Hemerocallis using rps16-trnK analysis

\begin{tabular}{lccccc}
\hline Taxa & A & C & G & T & Sites \\
\hline H. dumortieri & 0.408 & 0.146 & 0.138 & 0.308 & 738 \\
H. fulva var. kwanso & 0.414 & 0.148 & 0.139 & 0.299 & 742 \\
H. aurantiaca & 0.407 & 0.145 & 0.137 & 0.310 & 729 \\
H. coreana & 0.407 & 0.145 & 0.137 & 0.310 & 729 \\
H. littorea & 0.408 & 0.145 & 0.140 & 0.308 & 738 \\
H. minor & 0.408 & 0.145 & 0.138 & 0.308 & 737 \\
H. dumortieri var. esculenta & 0.407 & 0.147 & 0.138 & 0.308 & 737 \\
H. thunbergii & 0.407 & 0.142 & 0.140 & 0.312 & 738 \\
Mean & 0.408 & 0.146 & 0.138 & 0.308 & 736 \\
\hline
\end{tabular}


Table 3. Disparity index per site is shown for all sequence pairs in genus Hemerocallis using rps16-trnK analysis

\begin{tabular}{lcccccccc}
\hline Taxa & HDU & HCO & HDE & HTH & HMI & HAU & HFU & HLI \\
\hline HDU & - & & & & & & & \\
HCO & 0.000 & - & & & & & \\
HDE & 0.000 & 0.007 & - & & & & \\
HTH & 0.000 & 0.007 & 0.000 & - & & & - \\
HMI & 0.000 & 0.001 & 0.000 & 0.000 & - & 0.000 & 0.000 & - \\
HAU & 0.000 & 0.000 & 0.000 & 0.000 & 0.000 & 0.004 & 0.003 & \\
HFU & 0.000 & 0.000 & 0.000 & 0.000 & 0.000 & 0.003 & \\
HLI & 0.005 & 0.052 & 0.000 & 0.000 &
\end{tabular}

The taxon codes are the same as Table 1 .

Although several small indels and 20 inserts can be found, sequence variation within the Hemerocallis was mostly due to nucleotide substitutions. Another source of sequence divergence is length variation due to stretches of short repeats such as AAATA that occur at the intergenic spacer region in all the Hemerocallis.

$\mathrm{A}+\mathrm{T}$ content for eight Korean species of genus Hemerocallis ranged between $71.3 \%$ and $71.9 \%$ (Table 2). The base furtherance did not showed the significant difference to the by total taxa.

Disparity index per site is shown for all sequence pairs (Table 3). The eight among 28 pair indices were greater than 0 . Values greater exceeding 0 indicate the larger differences in base composition biases than expected based on evolutionary divergence between sequences and by chance alone.

Substitution pattern and rates were estimated under the Kimura 2-parameter model. The estimated Transition/
Table 4. Maximum likelihood estimate of the pattern of nucleotide sequences

\begin{tabular}{ccccc}
\hline Base & $\mathrm{A}$ & $\mathrm{T}$ & $\mathrm{C}$ & $\mathrm{G}$ \\
\hline $\mathrm{A}$ & - & 8.74 & 4.09 & 6.05 \\
$\mathrm{~T}$ & 11.52 & - & 6.22 & 3.86 \\
$\mathrm{C}$ & 11.52 & 13.27 & - & 3.86 \\
$\mathrm{G}$ & 18.05 & 8.74 & 4.09 & - \\
\hline
\end{tabular}

Each entry shows the probability of substitution (r) from one base (row) to another base (column). For simplicity, the sum of $r$ values is made equal to 100. Rates of different transitional substitutions are shown in bold and those of transversionsal substitutions are shown in italics. Codon positions included were $1 s t+2 n d+3 r d+N o n c o d i n g$. All positions containing gaps and missing data were eliminated. There were a total of 746 positions in the final dataset. Evolutionary analyses were conducted in MEGA5.

Transversion biases $(R)$ varied from 3.86 to 18.05 . Under maximum likelihood fits of 24 different nucleotide substitution models, Substitution from G to A was 18.05 and

Table 5. Results from Tajima's neutrality test for rps16-trnK sequences of genus Hemerocallis

\begin{tabular}{ccccccc}
\hline Group & M & S & ps & $\Theta$ & $\pi$ & D \\
\hline Taxa & 8 & 40 & 0.055 & 0.021 & 0.016 & -1.312 \\
\hline
\end{tabular}

$\mathrm{M}=$ number of sites, $\mathrm{S}=$ Number of segregating sites, $\mathrm{ps}=\mathrm{S} / \mathrm{M}, \Theta=\mathrm{ps} / \mathrm{a1}$, and $\pi=$ nucleotide diversity. $\mathrm{D}$ is the Tajima test statistic.

Table 6. The disparity index (below diagonal) per site and index test (upper diagonal) for all sequence pairs in genus Hemerocallis using rpsi6 and trnK

\begin{tabular}{lcccccccc}
\hline Taxa & HDU & HCO & HDE & HTH & HMI & HAU & HFU & HLI \\
\hline HDU & - & 0.927 & 0.984 & 0.984 & 0.999 & 0.996 & 0.999 & 0.992 \\
HCO & 0.076 & - & 0.937 & 0.937 & 0.925 & 0.923 & 0.925 & 0.924 \\
HDE & 0.016 & 0.065 & - & 0.999 & 0.983 & 0.980 & 0.983 & 0.976 \\
HTH & 0.016 & 0.065 & 0.001 & - & 0.983 & 0.980 & 0.983 & 0.976 \\
HMI & 0.001 & 0.078 & 0.017 & 0.017 & - & 0.997 & 0.997 & 0.993 \\
HAU & 0.004 & 0.080 & 0.020 & 0.020 & 0.003 & - & 0.997 & 0.991 \\
HFU & 0.001 & 0.078 & 0.017 & 0.017 & 0.003 & 0.003 & - & 0.991 \\
HLI & 0.008 & 0.079 & 0.024 & 0.007 & 0.007 & 0.009 & 0.009 & - \\
\hline
\end{tabular}

The taxon codes are the same as Table 1. 


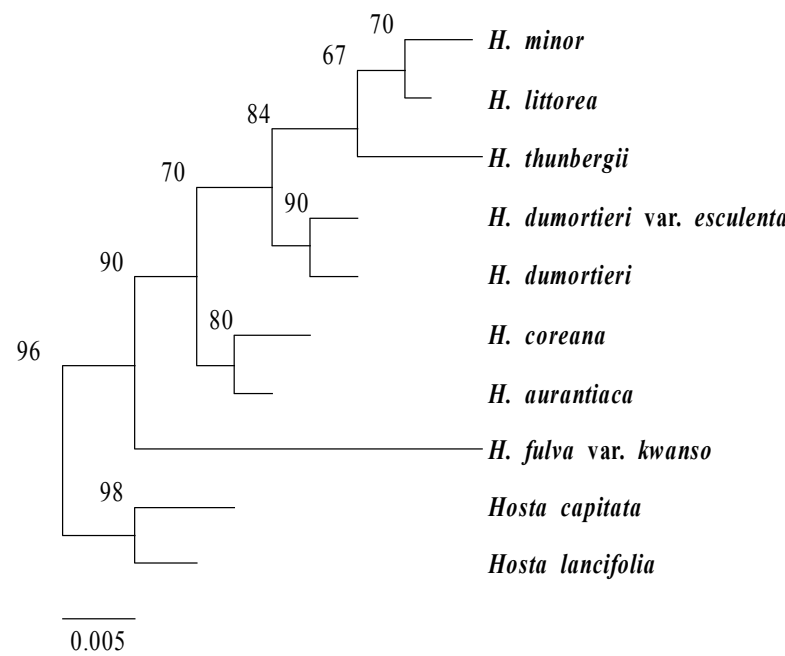

Fig. 1. The neighbor-joining tree for genus Hemerocallis based on rps16-trnK analysis using MEGA5. The value of bootstrap was shown in side of line.

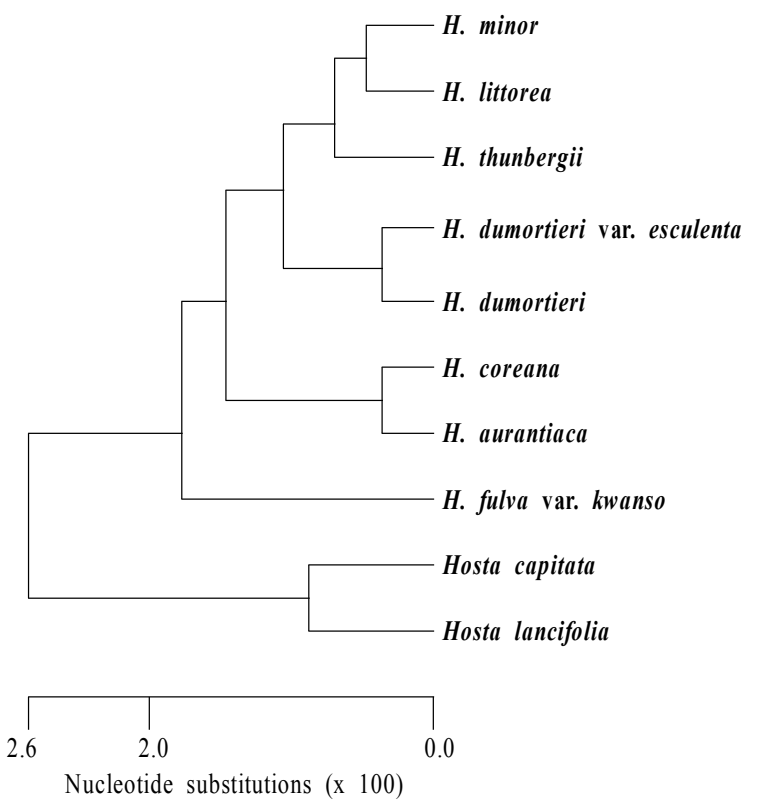

Fig. 2. The maximum likelihood tree for genus Hemerocallis based on rps16-trnK analysis using PAUP $4 \mathrm{~b} 10$.

the reverse was 6.05 (Table 4).

Number of segregating sites was 40 and nucleotide diversity $(\pi)$ was 0.016 . Under the neutral mutation hypothesis, the probability that $\mathrm{D}$ is negative $(-1.312)$ is less than 0.5 (Table 5). Therefore, there may be a site at which deletion/insertion, which increases the genetic variation, is operating.

Genetic distance $(D)$ based on the proportion of shared fragments was used to evaluate relatedness among species. The estimate of $D$ ranged from 0.001 to 0.080 (Table 6).

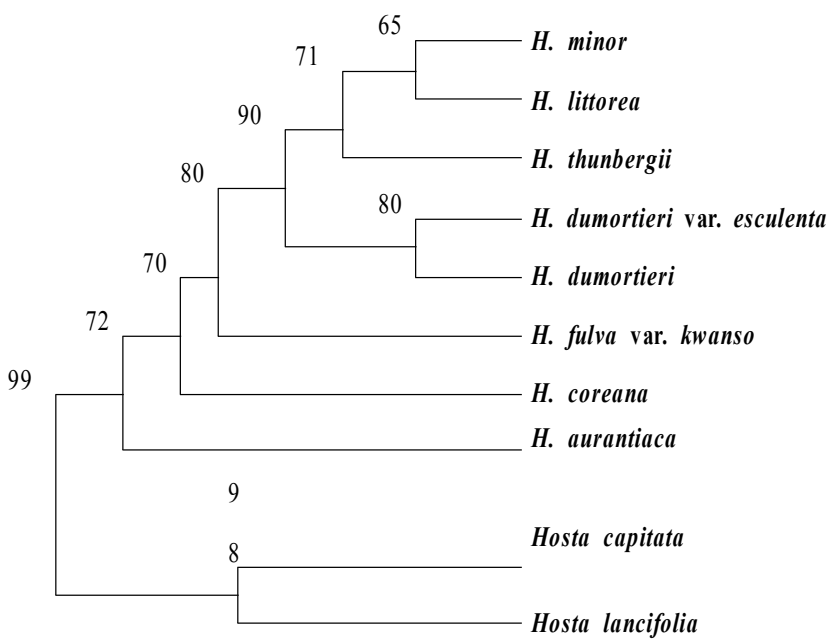

Fig. 3. The maximum parsimonious tree for genus Hemerocallis based on rps16-trnK analysis using PAUP 4b10, exhaustive search, unweighted parsimony analysis, gaps=fifth state) from the 751 aligned positions of the initial matrix. The values of bootstrap were shown in side of vertical line.

All $r p s 16-\operatorname{trn} K$ trees generated in Korea exhibited well solved topology with high bootstrap support irrespective of the methods (parsimony) and the setting used. This result confirmed monophyletic group for all species (Figs. 1, 2, 3). H. fulva var. kwanso was more distinct in $\mathrm{NJ}$ and ML trees. The main phylogenetic analysis revealed two distinct clades (Figs. 1 and 2). The first clade includes seven species. The second clade includes one species ( $H$. fulva var. kwanso). However, this node is not supported in maximum parsimonious (MP) tree (Fig. 3). The node of $H$ minor and $H$ littorea was strongly supported with a high bootstrap value in three trees and sistered with $H$ thunbergii. The node of $H$. dumortieri var. esculenta and $H$. dumortieri had also strongly supported with a bootstrap. The close relationships of $H$ minor, $H$. littorea, $H$. thunbergii, $H$. dumortieri var. esculenta, and $H$. dumortieri were supported with high bootstrap values. However, $H$ coreana, $H$. aurantiaca, and $H$. fulva var. kwanso were not significant incongruent in three trees.

\section{Discussion}

In order to further evaluate the suitability of the morphological characters traditionally used in the taxonomy of Hemerocalis, selected morphological characters were mapped onto the combined plastid phylogeny Hemerocalis. The evolutionary patterns encountered illustrate that some morphological characters traditionally used in the classification of 
Hemerocalis are homoplastic and are not adequate for the delimitation of generic boundaries. For example, morphologies (flowering time, order, color of perianth, shape of roots, length of perianth tube enclosing of ovary, and width of leaf) have been used to separate genus Hemerocalis. Flowering time was previously used to separate $H$. thunbergii which open in the daytime from other Hemerocalis species which open in the evening [10]. Conspicuous flower tubes were also previously used to separate $H$. dumortieri var. esculenta and $H$. dumortieri from the other species, but the phylogenetic relationships depicted here indicated that this character is homoplastic for $H$. aurantiaca and $H$. coreana present inconspicuous flower tubes.

On the other hand, other morphological features corroborate clades representing species and are good alternative for taxonomic use at this level $[6,10]$. For example, swollen roots have been mainly used to distinguish $H$. thunbergii from other species. Even though root pattern is homoplastic within $H$. coreana and $H$. minor, it is reliable for the separation of $H$ thunbergii from the other species. Flower color is also consistent at generic level in the group and is a good character for the separation of $H$. thumbergii from other species in this genus. This study also illustrated the difficulties of finding morphological synapomorphies within Hemerocalis. Most characters examined are homoplasious, with all characters analyzed appearing in overlapping combinations amongst Hemerocalis species and other genera of genus Hemerocalis. This finding suggests that morphological evolution of Hemerocalis was complex.

In the study with RAPD [6], $H$ fulva var. kwanso and $H$. thumbergii were grouped into small clades, while $H$. dumortieri and $H$ thunbergii have distinct relationships. The results by RAPD were not in agreement with our results obtained by rps16-trnK analysis. Chromosome numbers of $H$. dumortieri, $H$. coreana, $H$. middendorffi, $H$. thunbergii, and $H$. minor are $2 \mathrm{n}=22$ [9]. While that of $H$. fulva var. kwanso is $2 n=33$. This is in agreement with the results of this study. In addition, additional molecular experiments such as AFLP (amplified fragment length polymorphism), microsatellites, and ITS (nuclear ribosomal DNA internal transcribed spacer sequences) are necessary to identify species.

\section{References}

1. Andersson, L. and Rova, J. H. 1999. The rps16 intron and the phylogeny of the Rubioideae (Rubiaceae). Plant Syst Evol
214, 161-186.

2. Chung, M. 2000. Spatial structure of three populations of Hemerocalis hakuuensis. Bot Bull Acad Sci 41, 231-236.

3. Chung, M. G. and Kang, S. S. 1994. Morphometric analysis of the genus Hemerocallis L. (Lilisceae) in Korea. J Plant Res 107, 165-175.

4. Felsenstein, J. 1985. Confidence limits on phylogenies: An approach using the bootstrap. Evolution 39, 783-791.

5. Golenberg, E. M., Clegg, M. T., Durbin, M. L., Doebley, J. and Ma, D. P. 1993. Evolution of a noncoding region of the chloroplast genome. Mol Phylogenet Evol 2, 52-64.

6. Han, H. M. 1996. Detection of genetic variability in daylily genus (Hemerocallis) using randomly amplified polymorphic DNAs. Donguk University, MS.

7. Kang, S. S. and Chung, M. G. 1994. Hemerocallis hakuunensis (Liliaceae) in Korea. Sida 16, 23-31.

8. Kumar, S. and Gadagkar, S. R. 2001. Disparity Index: A simple statistic to measure and test the homogeneity of substitution patterns between molecular sequences. Genetics 158, 1321-1327.

9. Kwon, K. S. 1980. Morphological and cytological studies on the genus Hemerocallis in Korea. Ewha Womans University, MS., Seoul.

10. Lee, T. B. 2003. Coloured Flora of Korea. Hyangmoon Publishing Co., Seoul, Korea.

11. Matsuoka, N. and Hotta, M. 1966. Classification of Hemerocallis in Japan and its vicinity. Acta Phytotax Geobot 22, 22-25

12. Noguchi, J. and Hong, D. 2004. Multiple origins of the Japanese nocturnal Hemerocalis citrina. Int J Plant Sci 16, 219-230.

13. Noguchi, J., Hong, D. and Grant, W. F. 2004. The historical evolutionary development of Hemerocallis middendorfii (Hemerocallidaceae) revealed by non-coding regions in chloroplast DNA. Plant Syst Evol 247, 1-22.

14. Oxelman, B., Liden, M. and Berglund, D. 1997. Chloroplast rps16 intron phylogeny of the tribe Sileneae (Caryophyllaceae). Plant Syst Evol 206, 393-410.

15. Saitou, N. and Nei, M. 1987. The neighbor-joining method: A new method for reconstructing phylogenetic trees. $\mathrm{Mol}$ Biol Evol 4, 406-425.

16. Shaw, J., Lickey, E. B., Beck, J. T., Farmer, S. B., Liu, W., Miller, J., Siripun, K. C., Winder, C. T., Schilling, E. E. and Small, R. L. 2005. The tortoise and the hare II: relative utility of 21 noncoding chloroplast DNA sequences for phylogenetic analysis. Am J Bot 92, 142-166.

17. Swofford, D. L. 2003. PAUP*. Phylogenetic Analysis Using Parsimony ("and other methods). Version 4. Sunderland, Sinauer Associates, Inc. MA.

18. Stout, A. B. 1933. The flowering habits of daylilies. New York Bot Gard 34, 25-32.

19. Stout, A. B. 1935. The lemon daylily (Hemerocallis flava L.): its origin and status. New York Bot Gard 36, 61-68.

20. Stout, A. B. 1941. The inflorescence in Hemerocallis - 1. Bull Torr Bot Club 73, 134-154.

21. Tajima, F. 1989. Statistical methods to test for nucleotide mu- 
tation hypothesis by DNA polymorphism. Genetics 123, 585-595.

22. Tamura, K., Peterson, D., Peterson, N., Stecher, G., Nei, M. and Kumar, S. 2011. MEGA5: Molecular evolutionary genetics analysis using maximum likelihood, evolutionary distance, and maximum parsimony methods. Mol Biol Evol 28, 2731-2739.
23. Zomlefer, W. B. 1998. The genera of Hemerocallidaceae in the south-eastern United States. Harv Pap Bot 3, 113-145.

24. Zwickl, D. J. 2006. Genetic algorithm approaches for the phylogenetic analysis of large biological sequence datasets under the maximum likelihood criterion. Ph. D. dissertation, The University of Texas at Austin.

초록 : 엽록체 rps16-trnk 서열에 의한 한국 내 원추리속 식물종의 계통 관계

허만규 ${ }^{1} \cdot$ 권오성 ${ }^{1} \cdot$ 이병룡 ${ }^{2}$

( ${ }^{1}$ 동의대학교 자연과학대학 분자생물학과, ${ }^{2}$ 서원대학교 생물교육과)

원추리속 식물은 초본류이며 이 속의 일부 종은 약용으로 중요하다. 이 속의 8 개 분류군에 대해 엽록체의 rps16-trnK 부위로 계통관계를 평가하였다. 배당된 서열은 원추리(H. aurantiaca)에서 729 핵산 수로 가장 적었으 며 왕원추리(H. fulva var. kwanso)에서 742 핵산 수로 가장 많았다. 그 차이는 염기 삽입에 기인하였다. 비록 일부 인델(indel)과 20개 염기의 삽입이 발견되었지만 서열 내 변이는 염기 치환이 많았다. $r p s 16$ - trnK에 의한 한국 내 원추리속 분류군들은 높은 지지도로 잘 분리되었다. 애기원추리(H. minor)와 홍도원추리(H. littorea)는 높은 지 지도로 같은 분지군을 형성하였으며 이 분지군은 노랑원원추리와 자매군을 형성하였다. 염색체의 수는 기존 보 고된 RAPD의 결과와는 일치하지 않으나 본 연구와는 일치하였다. 